\title{
Practices, Challenges and Implications of Teaching and Assessment of Cognitive Skills in Higher Education
}

\author{
Malik Ghulam Behlol ${ }^{*}$ \\ Wasyl Cajkler $^{* *}$
}

\begin{abstract}
The key research questions of the study were to check understanding, practices and challenges in teaching and assessment of higher order thinking skills to students enrolled in pre-service teacher education program. Sequential mixed method design was applied to collect quantitative and qualitative data with the help of structured questionnaire scale and semi-structured interview. Descriptive statistics were applied by calculating percentages and means; and thematic analysis was carried out by open coding, axial coding, analytical coding and selective coding. Quantitative and qualitative data was integrated to draw findings and conclusions of the study. The major conclusions of the study are that faculty in UK conceptualise Cognitive Skills (CS) as processing information, constructing understanding, application of knowledge, problem solving and thinking activity. They also incorporate CSs in teaching problem solving and reflective learning practices in which learners retrieve, generate, organise, and validate information. They assess CSs by open book examination, moderation of assignments, matching and comparing against Teacher Education Standards, and also provide effective feedback. However, faculty do not focus on 'construction of theory' and linking theory to practice in teaching and assessment.
\end{abstract}

Keywords: cognitive skills, teaching, assessment, implications.

\footnotetext{
*Assistant Professor, Fatima Jinnah Women University Rawalpindi. Email: ghulam_behlol@yahoo.com

${ }^{* *}$ Professor, Education Department University of Leicester.
} 


\section{Introduction}

Teaching and assessment of CSs is significant for promoting understanding, conceptual development and to solve problems and make inventions. By promoting teaching and assessment of $\mathrm{CSs}$, and also learning how to use assessment information beyond generating marks and grades, we may enhance students' learning (Biggs, 1996; Anderson \& Krathwohl, 2001; Brookhart, 2010; Azzam, 2009; Barahal, 2008). According to Davis, Beyerlein, Leise and Apple (2005) learning processes in the cognitive domain include a hierarchy of skills involving processing information, constructing understanding, applying knowledge, solving problems, and conducting research. Processing information includes collecting data, generating data, organizing data, retrieving data, and validating information. Constructing understanding includes analyzing, synthesizing, reasoning, and validating understanding. Applying knowledge includes performing with knowledge, modeling, being creative, and validating results. Solving problems includes identifying the problem, structuring the problem, creating solutions, and improving solutions. Conducting research includes formulating research questions, obtaining evidence, discovering, and validating scholarship. It has been observed in the universities of Pakistan, by and large teaching and assessment of cluster CSs has been ignored because of multiple reasons (Iqbal \& Anwer, 2014; Naeemullah, Inamullah, Sarwar, Muhammad \& Hussain, 2010; Bashir, 2002). Majority of the teachers ask questions on their feet and only measure retention power of the students. Assessment of cognitive and higher order thinking skills are not given their due share in teaching and assessment (Iqbal, Anwer, 2014; Naeemullah, Inamullah, Sarwar, Muhammad \& Hussain, 2010; Bashir, 2002). Iqbal and Anwer (2014) conducted exploratory study about the assessment practices used by the teachers in B.ED (Hons) programme and revealed that intended learning outcomes are not aligned properly to all cognitive levels of Bloom' Taxonomy. $52 \%$ of the curriculum objectives of the course were confined to Remembering and Understanding level, whereas, $50 \%$ of the curriculum objectives of the course "General Methods of Teaching" were limited to the lowest cognitive levels of Bloom's Taxonomy. The document analysis of the mid-term and final-term papers revealed a lack of alignment of the assessment practices with the cognitive levels of Bloom's Taxonomy. A very small proportion of the final-term paper $(05 \%)$ was related to Evaluation level of the taxonomy. They are required to be aligned with the approaches toward learning and teaching 
embedded in the curriculum and instruction and also includes CSs (Martone \& Sireci, 2009 ; Arem, 2006; Azzam, 2009; Barahal, 2008; Martone \& Sireci, 2009).

\section{Cognitive-Constructivist Viewpoint about Teaching and Assessment}

Developments in the field of cognitive science has brought substantive changes in the assessment practices.Traditional paper and pencil tests are increasingly seen as misaligned with active learning approaches (Sweller; 2009; Wenglinsky, 2004). The learner centered, dynamic, and activity based learning approaches have led to an alternative set of assessment practices which are different from traditional paper and pencil approaches for assessing student outcomes (Anderson, 1998; Shepard, 2000). Instead of testing memory and recall knowledge, we need to prepare and train teachers to test the higher order thinking skills of the students. Cognitive, Constructive and Social constructive theories have reconceptualised classroom learning that has significant influence on Curriculum, Learning, and Assessment. Cognitive theory emphasizes that existing knowledge structures and beliefs work to enable or impede new learning. Intelligent thought involves self-monitoring and awareness to construct and adjust new learning to solve problems instead of just accumulation of information. School learning should be authentic and connected to the real life situation that makes it more interesting and motivating for students. In addition to the development of cognitive abilities, classroom expectations and social norms should foster the development of important dispositions, such as students' willingness to persist in trying to solve difficult problems. According to Shepard (2000):

"To be compatible with and to support this social-constructivist model of teaching and learning, classroom assessment must change in two fundamentally important ways. First, its form and content must be changed to better represent important thinking and problem solving skills in each of the disciplines. Second, the way that assessment is used in classrooms and how it is regarded by teachers and students must change. Furthermore, to enable this latter set of changes within classrooms, Teachers need help in fending off the distorting and de-motivating effects of external assessments". 
Content of assessment should match subject matter standards to improve the content and form of assessments. It may instantiate what it means to know and learn in each of the disciplines. It requires a broader range of assessment tools to address learning goals and processes that directly connect assessment to ongoing instruction. The reforms needed to devise more open-ended performance tasks to ensure that students are able to reason critically, to solve complex problems, and to apply their knowledge in real-world contexts. In addition, if instructional goals include developing students' metacognitive abilities, fostering important dispositions, and socializing students into the discourse and practices of academic disciplines, then it is essential that classroom routines and corresponding assessments reflect these goals as well. It means expanding the scope of data gathering to include observations, clinical interviews, reflective journals, projects, demonstrations, collections of student work, and students' self-evaluations, and systematic analysis of the available evidence by the teacher (Shepard, 2000).

\section{Research Questions}

Following three research questions set for the study

i. How do education faculty conceptualise and understand meanings of cognitive skills?

ii. How do education faculty practice teaching and assessment of cognitive skills?

iii. What are the major challenges to practice teaching and assessment of cognitive skills?

\section{Methodology of the Study}

It is descriptive-exploratory study to examine understanding and practices of Education Faculty about teaching and assessment of cognitive skills working in Higher Education in the selected Universities of UK under the lens of pragmatic paradigm of research. According to Patton (2002) a descriptive research defines what exist in natural setting to find out new realities and meanings without manipulation and control of the variables. Its purpose is to define or observe the features of a situation as it naturally happens. Pragmatists believe that every method has its own limitations that can be compensated by another method. They use not only deductive logic but also inductive logic to find out the solutions of problems. They think realities are multiple in nature, and 
there are different ways of inquiry to search answers of the research questions by using both qualitative and quantitative approaches.

\section{Design of the Study}

Sequential mixed method design was applied to conduct this study in two phases. The first phase was quantitative and the second phase was qualitative. The researcher collected data of first phase through questionnaire which was in numeric form. On the basis of quantitative data, an interview protocol was designed to crosscheck the findings of quantitative analysis. Consequently, qualitative and quantitative methods both were used to explore the answer of the research questions. All research questions were answered in both phases. In the first phase, awareness and understanding, practices in teaching and assessment, feedback, problems and challenges were answered through the four categories of questionnaire. In the second phase, interview protocol was designed to cross check the quantitative findings. The decision to take interviews of teachers after analyzing the quantitative data was made pragmatically on the basis of the contradictive quantitative results. The sources of triangulation in the study were the quantitative and qualitative responses of university teachers. According to Cohen and Manion(2008) triangulation is a technique that gives a balanced picture of human behavior in an unbiased and objective way.

\section{Population and Sample of the Study}

The population of the study was Faculty of Education from two public sector selected Universities of UK that were participating in project activities funded by Higher Education Commission Pakistan under Pakistan Program for Collaborative Research (PPCR). They were tutors, lecturers, assistant professors and professors. Because of time constraints and laborious ethical permission process, the researcher was able to collect data from the faculty members of three Universities applying convenient sampling technique. This small size of population was selected because of time constraints and laborious ethical approval process for participation in research. Population is not large enough to generalize the results of study with full confidence but sufficient enough to assess the situation at ground that may lead to conduct study on larger population by refining research questions. It may not only help to learn lessons and suggest recommendations but also support to plan a capacity building workshop for teaching and assessment of CSs in higher education. 
In the second phase, five faculty members were selected for interview applying criterion sampling technique. Only those faculty members who mostly disagreed with the statements of questionnaire were selected in order to cross check the data.

\section{Research Instruments}

Structured Questionnaire and semi-structured interview were used to collect the data of study. These instruments were developed by the research team and validated by the renowned experts of the University of Leicester and The Open University of Melton Kenes, UK. Instruments were also pilot tested before administration. Questionnaire consisted on four categories: demographic information, understanding, teaching and assessment of CSs. In qualitative approaches, interviews are considered as the most common tool for collection of data (Andrew \& Halcomb, 2009). Semi-structured interview was used to get in-depth information on particular issues (Holloway \& Wheeler, 2010). Pilot testing is useful to enhance the practical application, reliability and validity of the research instrument(Cohen, Manion \& Morrison, 2007). Best method to pilot test the instrument is to consult it with people included in population but not in the sample to anticipate the concerning issues (Walliman, 2011). Internal consistency of the instruments was checked through the Cronbach Alpha. Reliability statistics showed that total number of items was fifty-one and value of Cronbach Alpha was .89. As Gay suggested that the value of Alpha i.e. 0.75 is acceptable and more than .80 of it is highly significant (Gay, 2000). The consistency of the qualitative data was checked by interrater reliability.

\section{Data Collection and Analysis}

Data were collected by the researcher personally after getting consent from the faculty by showing ethical approval and briefing about the objectives of the study. Responses on the questionnaire categories were fed into SPSS and descriptive statistics were applied by calculating percentages and means to draw findings and conclusions. All interviews were audio recorded with the consent of participants. The researcher tried to remain unbiased and controlled personal effects during interviews and jotted down in field notes. Thematic analysis was carried out by open coding, axial coding, analytical coding and selective coding. At the completion of coding, I sent my original transcript to another qualitative scholar for coding of qualitative data then compared all codes 
from both sides. The coding matched well except for some minor differences. Approximately $90 \%$ yielded consistency in the coding differences were removed through discussions. Findings of quantitative and qualitative data were integrated to draw findings and conclusions of the study. Related ethical considerations were fully observed to conduct this study, and prior approval from the ethical committee of the UoL was obtained.

\section{Data Analysis}

Table 1

Demographic Variables $(n=10)$

\begin{tabular}{|c|c|c|c|c|c|c|c|c|c|}
\hline $\begin{array}{l}\text { Academic } \\
\text { qualification }\end{array}$ & $\mathrm{n}=1 \mathrm{c}$ & $\begin{array}{l}\text { Professional } \\
\text { Qualification }\end{array}$ & $\mathrm{n}=10$ & $\begin{array}{l}\text { Experience } \\
\text { (Year) }\end{array}$ & $\mathrm{n}=10$ & $\begin{array}{l}\text { Year } \\
\text { teaching }\end{array}$ & $\mathrm{n}=10$ & Role & $\mathrm{n}=10$ \\
\hline $\begin{array}{l}\text { BA(hon), } \\
\text { B.Ed. }\end{array}$ & 1 & & & $6-10$ & 2 & $1-5$ & 4 & Lecturer & 7 \\
\hline BSC(hons) & 1 & PGCE & 9 & $11-15$ & 2 & $6-10$ & 4 & $\begin{array}{l}\text { Associate } \\
\text { professor }\end{array}$ & 3 \\
\hline BSC,MSC & 2 & $\begin{array}{l}\text { HE } \\
\text { fellowship }\end{array}$ & 1 & $16-20$ & 4 & $20-25$ & 1 & & \\
\hline BSC,M.Ed & 2 & & & $21-25$ & 2 & 40 years & 1 & & \\
\hline MA & 2 & & & & & & & & \\
\hline Phd & 2 & & & & & & & & \\
\hline
\end{tabular}

Table 2

Section A: Understanding of Cognitive Skills

\begin{tabular}{|c|c|c|c|c|c|c|c|}
\hline Items & Mean & $\begin{array}{l}\text { Std. } \\
\text { Deviation }\end{array}$ & $\begin{array}{l}\text { Well } \\
\text { known } \\
\%\end{array}$ & $\begin{array}{l}\text { Very } \\
\text { well } \\
\text { known } \\
\%\end{array}$ & $\begin{array}{l}\text { Completely } \\
\text { unknown } \\
\%\end{array}$ & $\begin{array}{l}\text { Not } \\
\text { sure } \\
\%\end{array}$ & $\begin{array}{l}\text { Unknown } \\
\%\end{array}$ \\
\hline $\begin{array}{l}\text { CS involve processing } 10 \\
\text { information }\end{array}$ & 4.70 & 0.483 & 23.1 & 53.8 & 23.1 & 0 & 0 \\
\hline $\begin{array}{l}\text { CS involve constructing } \\
\text { understanding }\end{array}$ & 4.70 & 0.483 & 23.1 & 53.8 & 23.1 & 0 & 0 \\
\hline $\begin{array}{l}\text { CS generally involve } \\
\text { applying knowledge }\end{array}$ & 4.40 & 0.966 & 23.1 & 46.2 & 23.1 & 0 & 7.7 \\
\hline $\begin{array}{l}\text { CS with which I am } \\
\text { most familiar is } 9 \\
\text { problem solving }\end{array}$ & 4.22 & 0.667 & 38.5 & 23.1 & 7.7 & 0 & 30.8 \\
\hline $\begin{array}{l}\text { Definitions of CS do not } \\
\text { usually include } \\
\text { conducting research }\end{array}$ & 2.67 & 1.225 & 0 & 7.7 & 15.4 & 38.5 & 7.7 \\
\hline
\end{tabular}

$\mathrm{CS}=$ Cognitive Skills 
Table (2) shows that faculty of education understand meanings of the components of CSs that involves processing information with mean (4.70), constructing understanding with mean (4.70), applying knowledge with mean (4.40), familiar about problem solving with mean (4.22), conducting research with mean (2.67). Highest mean score (4.70) also shows that $23.1 \%$ faculty are well known that CS involves constructing understanding. Lowest mean score (2.67) depicted that faculty do not involve CSs for conducting research. Only $7.7 \%$ faculty are very well known that CSs usually include conducting research however $38.5 \%$ are not sure about this concept.

Table 3

Teaching of Cognitive Skills

\begin{tabular}{|c|c|c|c|c|c|c|c|c|c|}
\hline \multirow[t]{2}{*}{ Items } & \multirow[b]{2}{*}{$\mathrm{N}$} & \multirow[b]{2}{*}{ Mean } & \multirow[b]{2}{*}{ St.D } & \multirow{2}{*}{$\begin{array}{l}\text { Not } \\
\text { at } \\
\text { all }\end{array}$} & \multicolumn{3}{|c|}{ Seldom Occasionally often } & \multirow{2}{*}{$\begin{array}{l}\text { Every } \\
\text { session }\end{array}$} & \multirow{2}{*}{$\begin{array}{l}\text { Don't } \\
\text { know }\end{array}$} \\
\hline & & & & & & & & & \\
\hline $\begin{array}{l}\text { processing } \\
\text { information }\end{array}$ & 10 & 3.80 & 0.632 & 0 & 0 & 23.1 & 46.2 & 7.7 & 23.1 \\
\hline $\begin{array}{l}\text { collecting and } \\
\text { generating data }\end{array}$ & 10 & 3.50 & 0.707 & 0 & 7.7 & 23.1 & 46.2 & 0 & 23.1 \\
\hline organizing data & 10 & 3.50 & 0.707 & 0 & 7.7 & 23.1 & 46.2 & 0 & 23.1 \\
\hline $\begin{array}{l}\text { retrieving } \\
\text { information from a } \\
\text { range of sources }\end{array}$ & 10 & 4.00 & 0.816 & 0 & 0 & 23.1 & 30.8 & 23.1 & 23.1 \\
\hline $\begin{array}{l}\text { validating } \\
\text { information } \\
\text { retrieved }\end{array}$ & 10 & 3.70 & 0.949 & 0 & 7.7 & 23.1 & 30.8 & 15.4 & 23.1 \\
\hline
\end{tabular}

Table (3) reveals that faculty apply the components of CSs in teaching about processing of information with the mean (3.80), collecting and generating data with the mean (3.50), organising data with the mean (3.50), retrieving information from a range of sources with the mean (4.00) and validating information with the mean (3.70). However, percentage of frequencies reveals that $23.1 \%$ faculty occasionally practice and $23.1 \%$ do not know about the application of five components of CSs in their teaching. $46.2 \%$ of the faculty often practice the three components of CSs in their teaching (processing information, collecting and generating data, organizing data). 
Table 4

Providing opportunities to students to construct understanding and practice of cognitive skills

\begin{tabular}{|c|c|c|c|c|c|c|c|c|c|}
\hline \multirow[t]{2}{*}{ Items } & \multirow[b]{2}{*}{$\mathrm{N}$} & \multirow{2}{*}{\multicolumn{2}{|c|}{ Mean SD }} & \multicolumn{4}{|c|}{ Never Seldom Occasionally often } & \multirow{2}{*}{ Always } & \multirow{2}{*}{$\begin{array}{l}\text { Don't } \\
\text { know }\end{array}$} \\
\hline & & & & & & & & & \\
\hline $\begin{array}{l}\text { analysing (e.g. } \\
\text { teacher talk, } \\
\text { problems in the } \\
\text { classroom) }\end{array}$ & 10 & 4.20 & 0.919 & 0 & 7.7 & 0 & 38.5 & 30.8 & 23.1 \\
\hline synthesizing & 10 & 3.80 & 0.919 & 0 & 7.7 & 15.4 & 38.5 & 15.4 & 23.1 \\
\hline Reasoning & 10 & 4.20 & 0.632 & 0 & 0 & 7.7 & 46.2 & 23.1 & 23.1 \\
\hline
\end{tabular}

Table 4 reveals the percentage and mean score of faculty responses about the components of CSs that help students to construct understanding. Highest mean score identified towards "analysis" and "reasoning" (4.20), towards "synthesising" and "understanding" (3.80). $23.1 \%$ of the faculty do not provide opportunities to students in teaching for building their understanding by analysing, synthesising, reasoning and validating skills. $30.8 \%$ of the faculty apply analysing, $15.4 \%$ apply synthesising, $23.1 \%$ apply reasoning, and $15.4 \%$ apply validating to construct understanding in every session. 38.5\% apply analysing and synthesising, 46.2 apply reasoning and $30.8 \%$ reasoning often in their teaching session. 
Table 5

Conducting research is a requirement to assess students' skills

\begin{tabular}{|c|c|c|c|c|c|c|c|c|c|}
\hline Items & $\mathrm{N}$ & $\mathrm{M}$ & St. D & $\mathrm{SD}$ & $\mathrm{D}$ & NAND & A & SA & DNK \\
\hline Identifying a research problem & 10 & 4.30 & 0.483 & 0 & 0 & 0 & 53.8 & 23.1 & 23.1 \\
\hline $\begin{array}{l}\text { Formulating } \\
\text { questions }\end{array}$ & 10 & 4.10 & .568 & 0 & 0 & 7.7 & 53.8 & 15.4 & 23.1 \\
\hline Obtaining evidence & 10 & 4.70 & .483 & 0 & 0 & 0 & 23.1 & 53.8 & 23.1 \\
\hline $\begin{array}{l}\text { Discovering and validating } \\
\text { scholarship }\end{array}$ & 10 & 3.70 & .949 & 0 & 7.7 & 23.1 & 30.8 & 15.4 & 23.1 \\
\hline Locating relevant literature & 10 & 4.80 & .422 & 0 & 0 & 0 & 20.0 & 80 & 0 \\
\hline $\begin{array}{l}\text { Estimating } \\
\text { significance }\end{array}$ & 10 & 3.90 & .876 & 0 & 7.7 & 7.7 & 46.2 & 15.4 & 23.1 \\
\hline Designing experiments & 10 & 3.70 & 1.636 & 15.4 & 23 & 7.7 & 30.8 & 15.4 & 7.7 \\
\hline Reasoning with theory & 10 & 4.20 & .919 & 0 & 7.7 & 0 & 38.5 & 30.8 & 23.1 \\
\hline Constructing theory & 10 & 2.80 & 1.317 & 7.7 & 38.5 & 0 & 23.1 & 7.7 & 23.1 \\
\hline Defending prior work & 10 & 2.90 & .994 & 7.7 & 15.4 & 30.8 & 23.1 & 0 & 23.1 \\
\hline Responding to prior work & 10 & 3.60 & 1.265 & 7.7 & 7.7 & 77 & 38.5 & 15.4 & 23.1 \\
\hline
\end{tabular}

Table (6) reveals mean scores and percentages of faculty responses towards 'conducting research is a requirement to assess students' CSs. Mean score about 'identifying research problem' was (4.30) with $53.8 \%$ agree, $23.1 \%$ strongly agree and $23.1 \%$ do not know about it. Mean score about 'obtaining evidence' was (4.70) with $23.1 \%$ agree, $53.8 \%$ strongly agree and $23.1 \%$ do not know about it. Mean score about 'discovering and validating scholarship' was (3.70) with $30.8 \%$ agree, $15.4 \%$ strongly agree and $23.1 \%$ do not know about it. Highest mean score (4.80) calculated towards 'locating relevant literature' with $80 \%$ faculty strongly agree and $20 \%$ agree to the statement. Followed by high mean score (4.70) towards 'obtaining evidence' where $53.8 \%$ strongly agree while $23.1 \%$ agree to the statement. Mean score (4.30) identified towards 'identifying a research problem' where $53.8 \%$ agree with and $23.1 \%$ strongly agree.

Low mean score of (2.90) identified towards 'defining prior work' $23.1 \%$ agree to the statement and $15.4 \%$ disagree with. It is followed by lowest mean score of (2.80) towards' constructing theory' where $38.5 \%$ disagree with and $23.1 \%$ faculty agree with the statement. 
Table 6

Solving problems, a significant part of teaching

\begin{tabular}{lccccccccc}
\hline Items & $\mathrm{N}$ & $\mathrm{M}$ & St. D & SD & $\mathrm{D}$ & NAND & $\mathrm{A}$ & $\mathrm{SA}$ & DNK \\
\hline Identifying pedagogic problems & 10 & 4.50 & 0.527 & 0 & 0 & 0 & 38.5 & 38.5 & 23.1 \\
Structuring the problem & 10 & 4.20 & 0.422 & 0 & 0 & 0 & 61.5 & 15.4 & 23.1 \\
Creating solutions & 10 & 4.40 & 0.699 & 0 & 0 & 7.7 & 30.8 & 38.5 & 23.1 \\
Finding ways of improving solutions & 10 & 4.40 & 0.516 & 0 & 0 & 0 & 60 & 40 & 0 \\
\hline
\end{tabular}

Table (7) reveals views of teachers about 'solving problem' as a significance part of teaching. Highest mean score (4.50) was found about 'identifying pedagogical problems' with $38.5 \%$ faculty strongly agree and $38.5 \%$ agree to the statement. Mean score (4.40) identified towards 'creating solutions' and 'finding ways of improving solutions' with 38.5\% faculty strongly agree and $30.8 \%$ agree to the statement. However, $40 \%$ strongly agree and $60 \%$ agree towards 'finding ways of improving solutions'. Mean score (4.20) showed that $61.5 \%$ faculty agree to the statement of 'structuring the problem' and $15.1 \%$ strongly agree.

Table 7

Cognitive skills in teacher education program

\begin{tabular}{lccccccccc}
\hline Items & $\mathrm{N}$ & $\mathrm{M}$ & $\mathrm{St} . \mathrm{D}$ & $\mathrm{SD}$ & $\mathrm{D}$ & $\mathrm{NAND}$ & $\mathrm{A}$ & $\mathrm{SA}$ & $\mathrm{DNK}$ \\
\hline $\begin{array}{l}\text { Know how to assess } \\
\begin{array}{l}\mathrm{CS} \text { in pre-service } \\
\text { teacher education }\end{array}\end{array}$ & 10 & 3.80 & 0.422 & 0 & 0 & 15.4 & 61.5 & 0 & 23 \\
programs. & & & & & & & & \\
$\begin{array}{l}\text { My colleagues help } \\
\text { me to construct tests }\end{array}$ & 10 & 3.10 & 1.197 & 7.7 & 15.4 & 23.1 & 23.1 & 7.7 & 23 \\
to assess CS. & & & & & & & & \\
$\begin{array}{l}\text { Pre-service teacher } \\
\text { education prepared }\end{array}$ & 10 & 3.00 & 1.563 & 15.4 & 15.4 & 15.4 & 23.1 & 0 & 7.7 \\
me to teach CSs \\
effectively
\end{tabular}


Section $\mathrm{G}$ of the scale comprises of four sections. First section is analysed and presented in table 8. Mean score (3.80) showed that faculty 'know how to assess CSs in pre-service teacher education programs' where $61.5 \%$ faculty agree to the statement. Mean score (3.10) calculated towards 'my colleagues help me to construct tests to assess CSs' with $23.1 \%$ faculty agree and $7.7 \%$ strongly agree to the statement. Mean score (3) identified towards 'Pre-service teacher education prepared me to teach CSs effectively' however lowest mean score (2.70) identified towards 'Pre-service teacher education prepared me to assess CS effectively' with $23.1 \%$ disagree and $15.4 \%$ strongly disagree to the statement. 23\% faculty do not know and 15\% neither agree nor disagree about 'how to assess CSs in pre-service teacher education' and 'help of colleagues to construct test on CSs'.

Table 8

Practising Teaching of Cognitive Skills

\begin{tabular}{|c|c|c|c|c|c|c|c|c|c|}
\hline Items & $\mathrm{N}$ & $\mathrm{M}$ & StD & SD & $\mathrm{D}$ & NAND & A & SA & DNK \\
\hline $\begin{array}{l}\text { Find little time to } \\
\text { incorporate } \\
\text { teaching of CSs }\end{array}$ & 10 & 2.90 & 1.197 & 15.4 & 7.7 & 3.1 & 30.8 & 0 & 23 \\
\hline $\begin{array}{l}\text { CSs are useful to } \\
\text { solve real life } \\
\text { problems }\end{array}$ & 10 & 4.40 & 0.516 & 0 & 0 & 0 & 46.2 & 30.8 & 23 \\
\hline $\begin{array}{l}\text { Colleagues help } \\
\text { me to teach } \\
\text { incorporating } \\
\text { CSs }\end{array}$ & 10 & 3.40 & 1.075 & 0 & 15.4 & 30.8 & 15.4 & 15.4 & 23 \\
\hline $\begin{array}{l}\text { Need to make } \\
\text { classroom } \\
\text { adjustments } \\
\text { teach CSs }\end{array}$ & 10 & 3.20 & 0.789 & 0 & 15.4 & 30.8 & 30.8 & 0 & 23 \\
\hline $\begin{array}{l}\text { PBL enhances } \\
\text { students' CSs }\end{array}$ & 10 & 4.60 & 0.966 & 0 & 8.4 & 7.7 & 30.8 & 53.1 & 15.4 \\
\hline $\begin{array}{l}\text { Know how to } \\
\text { teach and assess } \\
\text { PBL }\end{array}$ & 10 & 3.90 & 1.101 & 0 & 7.7 & 15.4 & 38.5 & 7.7 & 7.7 \\
\hline $\begin{array}{l}\text { In teaching CSs, } \\
\text { I address } \\
\text { individual needs } \\
\text { of students }\end{array}$ & 10 & 4.20 & 0.919 & 0 & 0 & 15.4 & 38.5 & 15.4 & 7.7 \\
\hline
\end{tabular}


Table (9) presents faculty responses toward 'teaching of CSs'. Highest mean score (4.60) identified on the statement that 'PBL enhances students CSs' with $30.8 \%$ agree and $23.1 \%$ strongly agree to the statement. Followed by mean score (4.40) on the statement that 'CSs are useful to solve real life problems' with $46.2 \%$ agree and $30.8 \%$ strongly agree to the statement. Mean score on 'CSs useful to solve real problem, colleague helps me to teach CSs, need to make classroom adjustment to teach CSs, know how to teach and asses PBL, address individual needs of students' was found above the average mean scores $(4.40,3.40,3.20,3.90,4.20)$

Lowest mean score (2.90) calculated towards 'Find little time to incorporate teaching of CSs' with $30.8 \%$ agree with the statement. 
Table 9

Cognitive skills and assessment

\begin{tabular}{|c|c|c|c|c|c|c|c|c|c|}
\hline Items & $\mathrm{N}$ & M & StD & SD & DA & NAND & A & SA & DNK \\
\hline $\begin{array}{l}\text { Competent enough } \\
\text { to construct tests } \\
\text { incorporating CSs }\end{array}$ & 10 & 3.10 & 1.287 & 0 & 7.7 & 23.1 & 7.7 & 30.8 & 7.7 \\
\hline $\begin{array}{l}\text { Balance } \mathrm{LO} \text { and } \\
\mathrm{HO} \text { CSs in } \\
\text { designing teaching }\end{array}$ & 10 & 4.00 & 0.943 & 0 & 0 & 23.1 & 38.5 & 7.7 & 7.7 \\
\hline $\begin{array}{l}\text { Balance LO and } \\
\mathrm{HO} \text { CSs in } \\
\text { designing } \\
\text { assessments }\end{array}$ & 10 & 4.00 & 0.943 & 0 & 0 & 23.1 & 38.5 & 7.7 & 7.7 \\
\hline $\begin{array}{l}\text { Apply different } \\
\text { techniques to assess } \\
\text { the learning of CSs. }\end{array}$ & 10 & 3.70 & 0.483 & 0 & 0 & 23.1 & 53.8 & 0 & 23.1 \\
\hline $\begin{array}{l}\text { Have difficulties to } \\
\text { incorporate } \\
\text { assessment of CSs } \\
\text { Test rubrics help to }\end{array}$ & 10 & 3.00 & 0.667 & 0 & 15.4 & 46.2 & 15.4 & 0 & 23 \\
\hline $\begin{array}{ll}\text { assess } & \text { CSs } \\
\text { objectively } & \end{array}$ & 10 & 3.00 & 1.563 & 15.4 & 15.4 & 15.4 & 23.1 & 23 & 7.7 \\
\hline $\begin{array}{l}\text { Consult with my } \\
\text { students to set } \\
\text { criteria for the } \\
\text { assessment } \\
\text { CSs. }\end{array}$ & 10 & 2.10 & 0.738 & 15.4 & 38.5 & 23.1 & 0 & 0 & 23 \\
\hline $\begin{array}{l}\text { Assess performance } \\
\text { of students writing } \\
\text { of journals }\end{array}$ & 10 & 3.60 & 1.506 & 15.4 & 0 & 7.7 & 30.8 & 23.1 & 23 \\
\hline $\begin{array}{l}\text { Prefer to use open } \\
\text { ended tasks for } \\
\text { assessment of CSs }\end{array}$ & 10 & 3.90 & 0.876 & 0 & 7.7 & 7.7 & 46.2 & 15.4 & 23 \\
\hline $\begin{array}{l}\text { Always try to align } \\
\text { teaching and } \\
\text { assessment }\end{array}$ & 10 & 4.30 & 0.675 & 0 & 0 & 7.7 & 38.5 & 30.8 & 23 \\
\hline $\begin{array}{lr}\text { Consider } & \text { the } \\
\text { affective state } & \text { of } \\
\text { students } & \text { in } \\
\text { assessing CSs. } & \end{array}$ & 10 & 3.80 & 1.135 & 0 & 7.7 & 23.1 & 30.8 & 7.7 & 7.7 \\
\hline $\begin{array}{l}\text { Use assessment } \\
\text { results to modify } \\
\text { teaching practices }\end{array}$ & 10 & 4.50 & 0.527 & 0 & 0 & 0 & 38.5 & 38.5 & 23 \\
\hline $\begin{array}{l}\text { My teaching } \\
\text { activities guides the } \\
\text { assessment of CSs }\end{array}$ & 10 & 4.20 & 1.229 & 0 & 0 & 30.8 & 15.4 & 15.4 & 15.4 \\
\hline $\begin{array}{l}\text { Often study } \\
\text { researches on the } \\
\text { assessment of CSs. }\end{array}$ & 10 & 2.60 & 0.966 & 7.7 & 30.8 & 23.1 & 15.4 & 0 & 23 \\
\hline
\end{tabular}


Table (10) depicts faculty views towards use of CSs in assessment. High mean score (4.50) identified towards 'Use assessment results to modify teaching practices' with $38.5 \%$ faculty agree and strongly agree to the statement. It is followed by mean score (4.30), where $38.5 \%$ faculty agree and $30.8 \%$ strongly agree to the statement that they 'always try to align teaching and assessment'.

Responses of the faculty on the item 'Competent enough to construct tests incorporating CSs, Balance LO and HO CSs in designing teaching, Balance LO and HO CSs in designing assessments, Apply different techniques to assess the learning of CSs, Have difficulties to incorporate assessment of CSs, Test rubrics help to assess CSs objectively, Assess performance of students writing of journals, Prefer to use open ended tasks for assessment of CSs, Consider the affective state of students in assessing CSs, teaching activities guides the assessment of CSs' were found above average $(3.10,4.00,4.00,3.70,3.00,3.00,3.60,3.90,3.80$, 4.20).

$15.4 \%$ of the faculty disagree and $46.2 \%$ neither agree nor disagree on the statement 'Have difficulties to incorporate assessment of CSs. 38.5 of the faculty disagree and 23.1 neither agree nor disagree on the statement 'Consult with my students to set criteria for the assessment of CSs'.

Lowest mean score (2.10) calculated towards 'Consult with my students to set criteria for the assessment of CSs' with 38.5\% disagree and $15.4 \%$ strongly disagree with the statement. $23.1 \%$ of the faculty neither agree nor disagree on the statement 'Competent enough to construct tests incorporating CSs, Balance LO and HO CSs in designing teaching, Balance LO and $\mathrm{HO}$ CSs in designing assessments, Apply different techniques to assess the learning of CSs. 
Table 10

Cognitive Skills and Feedback to Students

\begin{tabular}{|c|c|c|c|c|c|c|c|c|c|}
\hline Items & $\mathrm{N}$ & $\mathrm{M}$ & StD & SD & $\mathrm{D}$ & NAND & $\mathrm{A}$ & SA & $\overline{D N K}$ \\
\hline $\begin{array}{l}\text { Provide feedback } \\
\text { to my students } \\
\text { based on clearly } \\
\text { defined criteria }\end{array}$ & 10 & 4.20 & 0.919 & 0 & 7.7 & 0 & 38.5 & 30.8 & 23 \\
\hline $\begin{array}{l}\text { Provide timely } \\
\text { feedback to my } \\
\text { students. }\end{array}$ & 10 & 4.40 & 0.699 & 0 & 0 & 7.7 & 30.8 & 38.5 & 23 \\
\hline $\begin{array}{lr}\text { My } & \text { students } \\
\text { usually r use } \\
\text { feedback } \\
\text { improve learning }\end{array}$ & 10 & 4.20 & 1.033 & 0 & 7.7 & 46.2 & 0 & 15.4 & 7.7 \\
\hline $\begin{array}{l}\text { Find it difficult to } \\
\text { provide feedback } \\
\text { to large classes }\end{array}$ & 10 & 3.20 & 1.135 & 0 & 30.8 & 7.7 & 30.8 & 7.7 & 23 \\
\hline $\begin{array}{l}\text { Check whether } \\
\text { feedback is used } \\
\text { by my students }\end{array}$ & 10 & 3.40 & 0.966 & 0 & 15.4 & 23.1 & 30.8 & 7.7 & 23 \\
\hline
\end{tabular}

Table (11) presents details about utilization of CSs and feedback provided to students. Mean score (4.40) identified towards 'Provide timely feedback to my students' with $38.5 \%$ faculty strongly agree and $30.8 \%$ agree to the statement. Mean score (4.20) identified towards 'Provide feedback to my students based on clearly defined criteria' and 'my students usually use feedback to improve learning'. $38.5 \%$ faculty agree and $30.8 \%$ strongly agree to the statement that 'they provide feedback to students based on criteria and $15.4 \%$ strongly agree that their students usually use feedback to improve learning.

Mean score (3.40) calculated towards the statement that 'check whether feedback is used by my students' with $30.8 \%$ agree and $15.4 \%$ faculty disagree to the statement.

Low level of mean score (3.20) calculated towards the statement that 'Find it difficult to provide feedback to large classes' with $30.8 \%$ faculty disagree to the statement.

\section{Qualitative Data Analysis}

Qualitative data collected with semi structured interview is analysed in this section. 


\section{Demographics of the Study Participants}

Five participants (four females and one male) participated in the study for the collection of qualitative data. Minimum level of the qualification of the participants was master and maximum was P.hD. Minimum experience of teaching was 6 years and the maximum duration of teaching experience was 20 years. Thematic analysis was conducted to analyse the qualitative data. Following main themes and sub themes emerged from the data.

\begin{tabular}{|c|c|}
\hline Main themes & Sub Themes \\
\hline Background and experience & $\begin{array}{ll}\text { - } & \text { Qualification/Specialization } \\
\text { - } & \text { Reason to join the profession }\end{array}$ \\
\hline Meaning and understanding of CSs & $\begin{array}{ll}\text { - } & \text { Understanding } \\
\text { - } & \text { Conceptualisation }\end{array}$ \\
\hline Teaching of cognitive skills & $\begin{array}{ll}\text { - } & \text { Methods of teaching } \\
\text { - } & \text { Collaboration with the colleges }\end{array}$ \\
\hline Assessment of cognitive skills & $\begin{array}{ll}\text { - } & \text { Criteria for assessment } \\
\text { - } & \text { Ways and methods of assessment } \\
\text { - } & \text { Grading the assignments } \\
\text { - } & \text { Reviewing assignments }\end{array}$ \\
\hline Provision of feed back & $\begin{array}{l}\text { - } \quad \text { Written feedback } \\
\text { - } \quad \text { Oral feedback }\end{array}$ \\
\hline $\begin{array}{l}\text { Challenges in teaching and } \\
\text { assessment of CSs } \\
\text { Suggestions to promote teaching and } \\
\text { assessment of cognitive skills }\end{array}$ & $\begin{array}{l}\text { - } \text { Differences in backgrounds and context } \\
\text { - } \text { Application of theory } \\
\text { - } \quad \text { Careful planning } \\
\text { - } \quad \text { Teachers awareness and training }\end{array}$ \\
\hline
\end{tabular}

Detailed description of qualitative data is as under:

\section{Background and Experiences}

Qualification and Teaching Experience All the participants (5) were working as teacher educators, and most of them also worked in schools before joining University. Their professional experience range was 6-20 years. P1 worked as head of the department of Geographyteaching, and also worked in secondary school for ten years. From last six years, he was working in teacher education in PGCE program. P2 had six-year experience of teaching in school before joining University. P3 worked as deputy course leader of PGCE and she had experience of 15 
years teaching at primary school alongside taking classes at university. P4 worked for 14 years in University. P5 worked for 6 years at Secondary School to teach Mathematics before joining University. Three out of five participants have educational background in Educational Psychology, one in Geography and one in Mathematics.

Reason for Joining Teacher Education P1 viewed, he joined teaching profession because of inclination and interest of research in pedagogy of Geography. P2 highlighted that she opted in teaching profession because of her previous experiences and work as Teacher Assistant. P3 told that her father and mother were also teachers, and they motivated her to opt for this profession. P5 stated that she joined this profession because of her interest and enjoyment to work and teach adults.

\section{Meaning and understanding of Cognitive Skills}

This theme interprets meaning, understanding and definition of CSs in the light of the views of participants. All of the participants have understanding of CSs and they defined it in different ways. According to $\mathrm{P} 1$, "it is a very broad area, to do something with the brain, remembering, analysing and interpreting things to solve problems". He further elaborated, it includes critical thinking, reflective thinking creativity and analytical thinking, using knowledge etc. Prior information is very important to practice higher order CSs to solve problems. He differentiated between the metacognition and critical thinking skills by stating that metacognition is more about understanding or reflecting whereas critical thinking is about actually taking information and evaluating their strengthen and weaknesses in different situations and contexts. P2 defined CSs as learning, attaining information, concentration, analytical skills, problem solving and making connection with the learned knowledge. According to P3, it includes learning and processing information. P4 elaborated that CSs mean to "do something with thinking, thinking about thinking, problem solving, and organizational skills".

\section{Teaching of Cognitive Skills}

Analysis about the teaching of CSs is explained under the following headings: 
Methods of teaching P1 shared that "setting focus of learning, teaching them basic information first and then asking students to apply knowledge to solve problems is the right approach to teach CSs". He further added that engaging students through critical thinking is the best way to teach CSs. He added that it is "providing resources (soft, paper), matter and events, deciding about the quantity of data, how to work on the information, and then framing questions and exercises to conduct learning of CSs". P2 stated that assessment comes at every stage and it starts from very beginning when a child enters in the schools. She added, "We get to know about the interests of children through assessment and we also know what they know before deciding what will be the next step. "Posing problem, providing opportunities of reflection, teacher confidence play a very important role in teaching of CSs". P3 shared that she does not teach students only for knowledge and understanding but also educate them how to learn. She further elaborated that she prefers to become model for them and uses questioning to create higher order thinking and analysing information rather than just hearing.

Collaboration with the colleagues According to $\mathrm{P} 1$ and $\mathrm{P} 2$, they conduct informal dialogues with their colleagues to comprehend teaching problems in reference to CSs. P3 shared that they discuss and share teaching challenges with their colleagues to address them effective, logical and practical way. P5 viewed, they conduct formal and informal meetings to share teaching and assessment challenges, and also conduct one to one corridor discussion. P4 stated that these learning conversation in formal and informal setting help to address daily problems and challenges in teaching of higher order thinking skills. These discussions also help to engage students in critical discussion.

\section{Assessment of Cognitive Skills}

Participants shared their views on assessment of CSs, and they are explained under the following sub themes:

Criteria for Assessment All the participants' agreed that they apply approved criteria to assess the performance of the students in assignment and projects by matching them against the Teaching Standards in PGCE program (P1,P2,P3,P4,P5). P5 also mentioned that criteria includes 5000 words for assignments (two assignments in one year, one is for 3000 words and one for 2000 words), critical understanding and practice of basic concepts related to teacher education and also moderation of 
assessment by the faculty. Students are not allowed to challenge the academic judgement given by the faculty. A student below $40 \%$ is considered fail. Furthermore, they assess students' observational skills and try to develop a sense of educational theory by critically analysing it. She highlighted that they assess the abilities and skills of the prospective teachers to work in different environment and dealing with students that have different backgrounds. P2 stated that "we also check how students interpret literature, apply it to promote theory and practice in teaching".

Ways and Methods of Assessment According to P1, "assessment of $\mathrm{CSs}$ is more appropriate through writing report, project presentation, review of literature, problem solving tasks, reflective journals, research projects, and reflective assignments instead of formal tests. P2 elaborated that "It is not testing; I look upon how they respond to a question, process data, infer insight to solve problem or respond to situation. She also viewed that careful curriculum planning, structuring pattern of thinking and provision of basic skills of the subject also play an important role in teaching and assessment of CSs. P3 shared her views in these words "I have common sense and experience to assess them on assessment tasks and check them on individual basis. We observe them in classroom, evaluate assignment organisation, critical analyses to and draw findings and conclusions. P4 shared her experience in these lines "Somehow, we teach them to promote CSs by confidence building, observing, reflecting, critically analysing and problem solving ways.

Grading the Assignments P3 expressed her thoughts in more detail and said "We check the quality of knowledge and understanding based on experience of students and application of CSs. So, I use analytical skills by listening to them what they say about particular situation. I think Standards of Teacher Education do not completely assess the CSs". Teaching Standards help us to assess the performance of students on broad area related to pedagogy, classroom management, assessment etc. In case of low performance on the part of students, extra work or repetition of tasks are also assigned to maintain minimum standards. Average 15 assignments per-semester is evaluated by a teacher. P4 also expressed similar thoughts in these words "we check confidence of students' in problem solving, reflective practices, critically analysis, linguistic capability through assignments and performance tasks at teaching practicum. We use a framework for their academic grade that is moderated by the faculty colleagues to finalise their grades in terms of formal assessment. 
Reviewing Assignments Participants also highlighted that the students' assignments were reviewed after the evaluation of subject teacher. Teachers who review the assignments called moderator. According to P2, Faculty fully cooperate in the review process and provide genuine input about the missing points and suggestions to support the students in learning and finalising their grades. P4 expressed that "students who get below 40\% marks in assignment, then, it is reviewed by the other faculty members to declare the repetition or promotion decision. They give their opinion and if someone failed the assignment, other colleagues check and put their comments and we make a decision". Students are not allowed to challenge academic judgement of the teachers.

\section{Provision of Feedback}

Feedback is very essential part of teaching and learning process. Themes and sub-themes emerged from the participants' views are as under:

Written feedback All the participants elaborated that they provide feedback in written form on the assignments/projects, and also provide oral Feedback about teaching, classroom management, research and assessment activities by identifying their strengths and weaknesses. P2 stated that detailed Feedback written on the hard copies by posing questions, suggesting helping material, practical tips to enhance learning of the prospective teachers to learn the art of profession. P3 viewed that Feedback sheet is handed over to students consisting on the blocks about writing styles, structuring and organisation, identifying gaps, critical analysis, and suggestions for improvement. P4 stated that Feedback is on the pattern of 'scaffolding learning' to help students to enhance their learning. Oral Feedback, according to P5 is provided after the observation of lesson, student teacher meeting to share achievements and problems to enhance the confidence of students.

Checking the feedback is followed or not All five participants elaborated, they check to what extent the student has utilised Feedback given on assignment one on the next assignment. P3 stated in case of major observation, we discuss with the students in face to face meeting how he/she has been benefitted by the Feedback and find out the reasons of missing of major suggestions. P4 stated that feedback is linked to Teacher Standards that may guide the faculty to identify the gaps that has 
to be covered by the students. According to P5, coversheet on the assignment attached by the student also explains how and to what extent feedback has been utilised by the student. In case of major observation, student has been asked to repeat the assignment.

\section{Challenges in Teaching and Assessment of Cognitive Skills}

Every society has challenges and obstacles in various fields to achieve the targets. Same is in the field of teacher education i.e. these challenges are of academic, pedagogical, research, management, relationship and linking theory to practice nature.

Differences in backgrounds and context The majority of the participants' highlighted that variety in background of the prospective teachers joining teacher education program is major challenge. They viewed that it is difficult for them to teach students with the background other than the social sciences. For instance, P2 stated that writing competencies, literature review, Science background, report writing skills are the major issues and challenges. P3 highlighted on the same issue in these words, "Every student is individual and has specific contextual background, temperaments that is required to be comprehended and addressed for the preparation of professionals. According to $\mathrm{P} 1$, to orientate students to conduct critical analysis is one of the major problems, and also to engage them to think and draw conclusions or solve problems by collecting, generating, processing, analysing, and interpreting information. Students are not tuned to do so as far as their learning in previous grades. It is also very challenging to connect theory to practice in learning the art of teaching profession.

\section{Suggestions for the Improvement}

The study participants shared some suggestion to improve the practices about teaching and assessment of CSs in higher education. These suggestions are discussed under the following sub themes.

Curriculum planning Curriculum planning is very important about teaching and assessment of CSs (P1). According to P2, curriculum planned in way that it promotes teaching and assessment of CSs incorporating higher order and lower order thinking skills. 
Application of theory P3 and P5 stressed over the practical application of the theory. By identifying the gaps between theory and practice, they suggested developing connections between theory and practice is also one of the major challenges in teaching and assessment of cognitive skills.

Session on cognitive skills P4 suggested to conduct a session on CSs and said, "Perhaps it would be useful as part of professional development. P5 also talked about the articulation and application of Bloom taxonomy.

\section{Discussion}

Quantitative and qualitative data triangulated and discussed under the headings of understanding of CSs, teaching of CSs, assessment of CSs and feedback practices.

It is revealed from quantitative data analysis that faculty thinks that CSs involve processing information, constructing understanding, application of knowledge and problem solving. These findings are corroborated with qualitative data analysis where all of the faculty members were of the view that CSs are related to remembering, processing information, thinking, analysing, interpreting, problem solving, reflecting and then it goes with understanding. Prior information is also important to conduct these processes. However, it is identified through quantitative and verified from the qualitative analysis that faculty thinks that CSs do not include 'conducting research' a component of CSs. It is also revealed that metacognition is more about understanding or reflecting whereas critical thinking is about actually taking information and evaluating their strengthen and weaknesses in different situations and contexts.

Quantitative data analysis revealed that faculty focus on the components of CSs: retrieving (from a range of sources), generating, organising, and validating information' into their teaching practices. Quantitative data also verified that problem solving as a component of CSs practiced in teaching, and they prefer on 'identification of pedagogic problems, generating solutions, and finding ways of improving solutions in teaching. Quantitative and qualitative analysis also revealed that the faculty provides opportunities to prospective teachers to enhance analysing, reasoning, synthesising skills to construct understanding. These findings are corroborated with qualitative data analysis that asking questions, setting problems and generating solutions is the right approach 
to teach CSs. Faculty was of the view that they prefer higher order thinking skills and analyze information. These findings are corroborated to cognitive theory that established that existing knowledge structures and beliefs work to support or impede new learning. Intelligent thought involves self-monitoring and awareness about when and how to use skills that promote expertise in coherent way of thinking and representing problems, not just as an accumulation of information. Critical thinking to CSs may enhance teaching and conceptual development for not only solution of problems rather may lead to innovation and creativity. Teachers are required to be competent enough to pose questions and engage students to reflect, analyse and induct and deduct conclusions. Cognitivists, Constructivists and Social constructivist theorists also agree that learning is active, intentional and intelligent activity to construct meaning in contrast to behaviorist mechanical approach of stimulus response connection. Although faculty agreed to the incorporation of CSs into teaching, however, they find little time to adjust it in classroom teaching.

It is concluded that they assess CSs in 'locating relevant literature' and 'obtaining evidence' that helps and guides to modify teaching practices. It was also revealed that the faculty is competent enough to construct tests that promote balanced assessment of lower order and higher order CSs. However, faculty do not focus on 'construction of theory' and linking theory to practice in teaching and assessment. And they also do not consult with their students to set criteria for assessment. Qualitative data contradicted quantitative data and revealed that they assess students' observational skills and try to develop a sense of educational theory. Majority of the respondents agreed that they know how to assess CSs in teacher education program, however, they disagreed that pre-service teacher education program prepared them enough to assess CSs effectively.

Students' assignments'/projects' are assessed by matching against Teacher Education Standards and moderated by the peer faculty. Critical understanding, organisation of content, review of literature, logical arguments are focused in the evaluation. A student below $40 \%$ is considered fail. Pedagogical skills based on teaching standards are given consideration in teaching practice and skills of the prospective teachers to work in different environment. CSs are better assessed from writing report, project presentation, and review of literature, problem solving tasks, reflective journals, research projects, and reflective assignments instead of formal tests. In case of low performance on the part of students, extra work or repetition of tasks are also assigned to maintain 
minimum standards. Cognitive psychologists also recommend that open book examination, reflective journal, project assignments are more useful instead of traditional paper and pencil tests for active and meaningful learning. The learner centered, dynamic, and activity based learning and assessment approaches are more effective for the assessment of cognitive and higher order thinking skills(Shepard, 2000).

It is identified from quantitative data that faculty provide timely feedback to students based on clearly defined criteria', and students usually use feedback to improve learning. Qualitative data also highlighted same opinions of faculty that they provide feedback to their students in written form as writing notes, strengths and weaknesses and targets for the next assignment. Contradictory views were found through qualitative data analysis about whether the students worked on the given feedback or not. Two of them told that they require a written report from the students and three of them viewed that they check the feedback incorporation in the next assignment instead of written report. They also viewed that feedback is provided on clearly defined criteria and students usually use it to improve learning.

Different academic backgrounds of the prospective teachers joining teacher education program was considered major challenge followed by writing competencies, analysing and reflective skills, collecting, organising and generating data for problem solving. Curriculum planning, building professional competencies are suggested to be enhanced for teaching and assessment of CSs. Linking theory to practice is an important to enhance teaching skills of the prospective teachers.

\section{Recommendations}

Following are the recommendations

Assessment practices are required to support and enhance learning instead of only measuring, scoring and grading. Classroom assessment is suggested to be changed in two ways: form and content. It may represent thinking, reflecting and problem solving skills of a discipline. We need to create and promote a learning culture where students and teachers would have a shared understanding, expectation and responsibilities about assessment. They (students \& teachers) look to assessment as a source of insight and help instead of an instrument for meeting out rewards and punishments. 
Reforms are needed to devise more open-ended performance tasks to ensure that students are able to reason critically, to solve complex problems, and to apply their knowledge in real-world contexts. It means expanding the scope of data gathering to include observations, clinical interviews, reflective journals, projects, and demonstrations, collections of student work, and students' self-evaluations, and systematic analysis of the available evidence by the teacher.

Existing practices of high stake testing required to be replaced by dynamic, on-going and self-assessment practices. Teachers try their level best to raise the scores of students to meet political demands and satisfy the parents in reference to getting admission for attractive and high paying professions. These tests have a corrupting influence on students' learning and leads to the de-skilling and de-professionalization of teachers.

Feedback for the learner may lead to self-correction and improvement. Only reporting of right and wrong answers to the learner, and the end-ofstudy test may not be enough. Observation feedback forms, as well as training in lesson analysis, will provide evaluation tools for supporting (and assessing) classroom practice.

Attention to both cognitive and affective domains is required to be given balance weightage in testing and assessment. We cannot separate them and both effect each other. We need to understand humans holistically; cognition and affect should not be separated. 


\section{References}

Anderson, L. W., \& Krathwohl, D. R. (Eds.). (2001). A taxonomy for learning, teaching, and assessing: A revision of Bloom's Taxonomy of Educational Objectives. New York: Longman.

Andrew, S \& Halcomb, E. J (2009). Mixed Methods Research for Nursing and the Health Sciences. Chichester, West Sussex Blackwell Publishing Ltd

Arem, G. (2006). Using student assessments in archery to increase higher-order thinking and student success. Strategies, 19(4), 34-38.

Azzam, A. M. (2009). Why creativity now? A conversation with Sir Ken Robinson. Educational Leadership, 67(1), 22-26.

Barahal, S. L. (2008). Thinking about thinking. Phi Delta Kappan, 90(4), 298-302.

Bashir, M. (2002). A study of examination system of Pakistan and development of a model for twenty first century (Doctoral dissertation, PMAS-Arid Agriculture University, Rawalpindi).

Biggs, J. (1996). Enhancing teaching through constructive alignment. Higher Education, 32(3), 347-364.

Brookhart, S.M. (2010). Assess higher order thinking skills in your classroom. ASCD, Alexandira, Virginia:

Cohen, L., Manion, L., \& Morrison, K. (2013). Research methods in education. Routledge

Creswell, J. W. \& Clark, V. L. P. (2007).Designing and Conducting Mixed Methods Research' Sage Publications Ltd, USA.

Davis, D., Beyerlein, S.W. Leise, C., \& Apple, D. K. (2005). Cognitive Domain, Faculty Development Series, Washington: Pacific Crest Foundation.

Gay, L. R. (2000). Educational Research. $5^{\text {th }}$ ed. Merrill Publishing Company

Holloway, I., \& Wheeler, S. (2010). Qualitative Research in Nursing and Healthcare. Chichester: Wiley-Blackwell 
Iqbal, B., Anwer, M. (2014). An exploratory study of assessment practices at B.ED (Hons) 4 years program. Unpublished research, USAID, Islamabad:

Martone, A., \& Sireci, S. G. (2009). Evaluating alignment between curriculum, assessment, and instruction. Review of Educational Research, 79(4), 13-32.

Naeemullah, K., Muhammad, I. H., Muhammad, S., Uddin, M. N., \& Shafqat, H. (2010). The managerial behavior of secondary school heads in Punjab (Pakistan). Educational Research and Reviews, 5(4), 186.

Patton, M. Q. (2002) Qualitative Research and Evaluation Methods. (3rd Edition) Thousand Oaks, CA: SAGE.

Shepard, L. A. (2000). Measuring achievement: What does it mean to test for robust understanding! Princeton, NJ: Policy Information Center, Educational Testing Service. Shepard, L. A. (2000). The Role of Assessment in a Learning Culture. Teaching and Learning, 229-253.

Sweller, J. (2009). Cognitive bases of human creativity. Educational Psychology Review, 21(1), 11-19.

Vygotsky, L. S. (1978). Mind in society: The development of higher psychological processes. Cambridge, MA: Harvard University Press.

Walliman, N. (2011) Your Research Project: Designing and planning your work, ThousandOaks, CA: Sage Publications Ltd.

Wenglinsky, H. (2004). Facts or critical thinking skills? What NAEP results say. Educational Leadership, 62(1), 32-35.

\section{Citation of this Article:}

Behlol, M. G., \& Cajkler, W. (2018) Practices, challenges and implications of teaching and assessment of cognitive skills in higher education. Pakistan Journal of Education, 35(1), 113-140.

Received on: September 21, 2017

Revised on: March 16, 2018

Accepted on: March 28, 2018 